\title{
Phenotypic and molecular characterization of erythromycin resistance in Campylobacter jejuni and Campylobacter coli strains isolated from swine and broiler chickens ${ }^{1}$
}

\author{
Thomas S. Dias ${ }^{2 *}$ (D), Leandro S. Machado ${ }^{2,3}$ (D) Julia A. Vignoli ${ }^{3}$, Nathalie C. Cunha ${ }^{3}$, \\ Elmiro R. Nascimento ${ }^{2,3}$, Virginia Léo A. Pereira ${ }^{2,3}$ and Maria Helena C. Aquino ${ }^{2,3}$
}

\begin{abstract}
Dias T.S., Machado L.S., Vignoli J.A., Cunha N.C., Nascimento E.R., Pereira V.L.P. \& Aquino M.H.C. 2020. Phenotypic and molecular characterization of erythromycin resistance in Campylobacter jejuni and Campylobacter coli strains isolated from swine and broilers. Pesquisa Veterinária Brasileira 40(8):598-603. Faculdade de Veterinária, Universidade Federal Fluminense, Rua Vital Brazil Filho 64, Niterói, RJ 24230-340, Brazil. E-mail: thomassalles@id.uff.br

Campylobacter spp. is a bacterial agent that causes gastroenteritis in humans and may trigger Guillain-Barré Syndrome (GBS) and is also considered one of the main foodborne diseases in developed countries. Poultry and pigs are considered reservoirs of these microorganisms, as well as raw or undercooked by-products are often incriminated as a source of human infection. Treatment in human cases is with macrolide, such erythromycin, that inhibits the protein synthesis of the microorganism. This study aimed to isolate Campylobacter jejuni and Campylobacter coli from intestinal content samples of broiler chickens $(n=20)$ and swine $(n=30)$ to characterize the erythromycin resistance profile of the strains and to detect molecular mechanisms involved in this resistance. The minimum inhibitory concentration was determined by agar dilution. The Mismatch Amplification Mutation Assay-Polymerase Chain Reaction (MAMA-PCR) was performed to detect mutations at positions 2074 and 2075 of $23 \mathrm{~S}$ rRNA region, in addition to PCR test to detect the erm(B) gene. From the intestinal content of broiler chickens, 18 strains of $C$. jejuni and two strains of $C$. coli were isolated, whereas, from swine samples, no $C$. jejuni strain and 14 strains of $C$. coli were isolated. All $C$. coli strains were resistant, and three $C$. jejuni strains from broilers chickens were characterized with intermediate resistance to erythromycin. The MIC of the strains ranged from $\leq 0.5 \mathrm{mg} / \mu \mathrm{L}$ to $\geq 128 \mathrm{mg} / \mu \mathrm{L}$. All resistant strains had the $\mathrm{A} 2075 \mathrm{G}$ mutation, and one strain with intermediate resistance had the A2075G mutation. However, the A2074C mutation and the erm(B) gene were not detected. High resistance levels were detected in $C$. coli strains isolated from swine. The MAMA-PCR is a practical tool for detecting the erythromycin resistance in Campylobacter strains.
\end{abstract}

INDEX TERMS: Phenotype, molecular characterization, erthromycin resistance, Campylobacter jejuni, Campylobacter coli, strains, swine, broiler chickens, foodborne pathogens, MAMA-PCR, macrolides, A2075G.

\begin{abstract}
RESUMO.- [Caracterização fenotípica e molecular da resistência à eritromicina em cepas de Campylobacter jejuni e Campylobacter coli isoladas de suínos e frangos de corte.]
\end{abstract}

\footnotetext{
${ }^{1}$ Received on December 7, 2019.

Accepted for publication on March 30, 2020.

${ }^{2}$ Graduate Program in Veterinary Medicine with emphasis in Veterinary Hygiene and Technological Processing of Products of Animal Origin, Faculdade de Veterinária, Universidade Federal Fluminense (UFF), Rua Vital Brazil Filho 64, Niterói, RJ 24230-340, Brazil.*Corresponding author: thomassalles@id.uff.br

${ }^{3}$ Departamento de Saúde Coletiva Veterinária e Saúde Pública, Universidade Federal Fluminense (UFF), Rua Vital Brazil Filho 64, Niterói, RJ 24230-340, Brazil.
}

Campylobacter spp. é um agente bacteriano causador de gastroenterite em humanos e associado à síndrome de Guillain-Barré, sendo a campilobacteriose considerada uma das principais enfermidades de origem alimentar. Aves e suínos são importantes reservatórios desses microrganismos e seus produtos derivados crus ou mal cozidos são muitas vezes incriminados como fonte de infecção humana. A primeira escolha para o tratamento em casos humanos são os antimicrobianos da classe dos macrolídeos como à eritromicina. Dentro desse contexto, o objetivo deste estudo foi isolar Campylobacter jejuni e C. coli a partir de 20 amostras 
de conteúdo intestinal de frangos de corte e de 30 de suínos ao abate e investigar a resistência à eritromicina das estirpes obtidas e os possíveis mecanismos moleculares envolvidos nesta resistência. A concentração inibitória mínima foi determinada pela diluição em ágar e a técnica MAMA-PCR foi utilizada para detecção de mutações nas posições 2074 e 2075 da região 23s rRNA, foi pesquisado também a presença do gene erm(B) pela PCR. A partir do conteúdo intestinal de frangos de corte foram isoladas 18 estirpes de $C$. jejuni e duas de $C$. coli, enquanto de suínos foram obtidas 14 estirpes de $C$. coli e nenhuma estirpe de $C$. jejuni. Todas as estirpes de $C$. coli de suínos foram identificadas como resistentes e três estirpes de $C$. jejuni de frangos foram caracterizadas com resistência intermediária. A CIM das estirpes variou de $\leq 0,5 \mathrm{mg} / \mu \mathrm{L}$ a $\geq 128 \mathrm{mg} / \mu \mathrm{L}$. Todas as estirpes resistentes tinham a mutação A2075G e uma cepa com resistência intermediária também apresentou a mutação A2075G. Não foi detectada a mutação A2074C ou a presença do gene erm(B) em nenhuma das estirpes obtidas. Os resultados revelam um alto nível de resistência em estirpes de $C$. coli isoladas de suínos frente a eritromicina. A técnica MAMA PCR utilizada se constitui em uma ferramenta prática para detecção da resistência à eritromicina em estirpes de $C$. jejuni e $C$. coli.

TERMOS DE INDEXAÇÃO: Caracterização fenotípica, caracterização molecular, resistência à eritromicina, cepas, Campylobacter jejuni, Campylobacter coli, suínos, frangos de corte, patógenos de origem alimentar, macrolídeos, MAMA-PCR, A2075G.

\section{INTRODUCTION}

Campylobacter spp. is a bacterial agent that causes gastroenteritis in humans and despite its importance in unique health, studies on human campylobacteriosis in Brazil are scarce. However, in the European Union (EU), campylobacteriosis is the leading disease that has its agent transmitted by food, since 2004 (Gibbons et al. 2014, EFSA \& ECDC 2018a, 2018b). Among the main reservoirs of these microorganisms, birds and pigs stand out, with the same genotypes of Campylobacter spp. being reported in some countries, circulating between humans and domestic animals, thus reinforcing their zoonotic potential. The transmission of microorganisms to people can occur through the ingestion of contaminated animal products and direct contact with animal feces (Wilson et al. 2008, Rosner et al. 2017, Asakura et al. 2019). Human campylobacteriosis is usually self-limiting, but in some cases treatment is performed with macrolide antibiotics (Bolinger \& Kathariou 2017).

The use of (WHO 2013), especially in farm animals, allow the selection of resistant strains in livestock. Thus, there is the possibility of contamination of animal origin products with resistant strains, which can lead to the subsequent infection of people who consume these products (Pyörälä et al. 2014). Antibiotics of the macrolide class can act by inhibiting protein synthesis in the 50s subunit of ribosomal RNA by interrupting peptide translocation that prevents protein synthesis. Erythromycin is considered to be the representative of this class (Vázquez-Laslop et al. 2018).

The primary mechanism that confers high levels of resistance to macrolides in Campylobacter spp. involves a modification of the antimicrobial binding site to the ribosome by a point mutation at the target site in the peptidyl transferase region regarding the $23 \mathrm{~S}$ region of the ribosomal RNA gene. In this mechanism, adenine is replaced by guanine at position 2075 and/or by cytosine at position 2074 (Alonso et al. 2005, Ladely et al. 2009). At the same time, low levels of resistance to macrolides occur due to mutations in genes that encode ribosomal proteins, such as L4 and L22 (Luangtongkum et al. 2009). For many years, it has been accepted that high levels of resistance to macrolides in Campylobacter spp. occurred exclusively due to mutations in the $23 \mathrm{~S}$ rRNA region associated with efflux pumps, such as CmeABC. However, Qin et al. (2014) identified the presence of the $\operatorname{erm}(\mathrm{B})$ gene in a strain of $C$. coli. This gene encodes a methylase that mediates high resistance levels to macrolides and can be transferred through bacterial transformation, a frequent mechanism in Campylobacter spp. (Wiesner et al. 2003). Through horizontal transmission, there is a higher possibility of spread resistance among strains (Qin et al. 2014, Wang et al. 2014). To date, strains of Campylobacter spp. possessing the erm(B) gene has only been described in isolates in China, Spain, and the United States of America (USA) (Qin et al. 2014, Wang et al. 2014, Florez-Cuadrado et al. 2016, Zhang et al. 2016, Chen et al. 2018).

The detection of these point mutations can be performed through sequencing, a technique with high accuracy, high cost, and limited availability in laboratories. Therefore, Alonso et al. (2005) described a specific Polymerase Chain Reaction (PCR) to detect mutations in the 23rRNA region, called Mismatch Amplification Mutation Assay-PCR (MAMA-PCR). This technique can detect these point mutations without the need for DNA sequencing, once these mutations are already known. The MAMA-PCR uses a conserved forward primer from the 23S rRNA region in conjunction with the ERY2075-R/ERY2074-R reverse primers to detect A2075G/ A2074C mutations. A 485 bp PCR product is generated when the isolates have the corresponding mutation (Han et al. 2016). Several studies have already reported the efficiency of MAMA-PCR for detecting mutations in the 23S rRNA region when compared to DNA sequencing techniques (Qin et al. 2011, Giacomelli et al. 2012, Maćkiw et al. 2012, Han et al. 2016, Zhang et al. 2016).

This study aimed to isolate Campylobacter spp. from the intestinal content of swine and broiler chickens, characterize the profile of resistance to erythromycin of these strains, and to detect molecular mechanisms involved in this resistance.

\section{MATERIALS AND METHODS}

Material collection. The project was submitted to and approved by the Animal Ethics Council of "Universidade Federal Fluminense" (UFF) under number 5223141018. From September to November 2018, intestines of 20 broiler chickens ( 10 animals/batch), slaughtered under state sanitary inspection, and intestinal content of 30 swines (10 animals/batch), slaughtered under federal inspection were collected, the animals came from the states of Rio de Janeiro and Minas Gerais, respectively. The intestines and intestinal contents were sent to the "Laboratório de Doenças Infecciosas", at the "Faculdade de Veterinária" (UFF,) in isothermal boxes and processed on the same day of collection.

Isolation and identification. An aliquot of the content was diluted in $3 \mathrm{~mL}$ of sterile distilled water with subsequent filtration through a $0.65 \mu \mathrm{M}$ filter membrane (Sartorius). The filtrate was streaked on Columbia Agar (Kasvi, Brazil) supplemented with $0.4 \%$ activated carbon and selective supplement CAMPYLOFAR ${ }^{\circledR}($ CEFAR, Brazil). The plates were incubated at $37^{\circ} \mathrm{C}$ under microaerophilia for 
48 hours, and colonies were selected for presumptive identification, due to their morphotintorial characteristics, and later identification by PCR. According to Sambrook et al. (2006), strains of DNA were extracted by the phenol-chloroform method. Multiplex PCR was performed to identify the species (Harmon et al. 1997 modified by Aquino et al. 2002). The amplification reaction was performed with a final volume of $50 \mu \mathrm{L}$, containing $5 \mu \mathrm{L}$ of the sample DNA, 1X PCR Buffer (500mM KCl, $100 \mathrm{mM}$ Tris- $\mathrm{HCl}$ [pH 8.5]), 5.5mM/L $\mathrm{MgCl}_{2}$, $0.4 \mu \mathrm{M} d \mathrm{NTP}, 0.4 \mu \mathrm{M}$ of each primer pg3 and pg50, $0.2 \mu \mathrm{M}$ of each primer $\mathrm{C} 1$ and $\mathrm{C} 4$ and $2.5 \mathrm{U}$ of Taq DNA polymerase (Invitrogen, Brazil). Initial denaturation was carried out at $94^{\circ} \mathrm{C}$ for four minutes, followed by 25 amplification cycles consisting of one minute at $94^{\circ} \mathrm{C}$, one minute at $55^{\circ} \mathrm{C}$, one minute at $72^{\circ} \mathrm{C}$ and final extension at $72^{\circ} \mathrm{C}$ for seven minutes. Strains of Campylobacter jejuni ATCC 33560 and Campylobacter coli NCTC 11366 were used as positive controls of the reaction.

Minimum inhibitory concentration. The sensitivity of Campylobacter spp. to erythromycin was determined by the antibiotic dilution method on agar to determine the Minimum Inhibitory Concentration (MIC) according to the criteria determined by the Clinical and Laboratory Standards Institute (CLSI 2010). The concentrations of erythromycin used were $128 \mu \mathrm{g} / \mathrm{mL}, 64 \mu \mathrm{g} / \mathrm{mL}$, $32 \mu \mathrm{g} / \mathrm{mL}, 16 \mu \mathrm{g} / \mathrm{mL}, 8 \mu \mathrm{g} / \mathrm{mL}, 4 \mu \mathrm{g} / \mathrm{mL}, 2 \mu \mathrm{g} / \mathrm{mL}, 1 \mu \mathrm{g} / \mathrm{mL}$ and $0.5 \mu \mathrm{g} /$ $\mathrm{mL}$. The breakpoint for erythromycin was defined according to the established by CLSI (2013), where strains with a MIC of up to $8 \mu \mathrm{g} /$ $\mathrm{mL}$ were considered sensitive, $16 \mu \mathrm{g} / \mathrm{mL}$ intermediate and $\geq 32 \mu \mathrm{g} /$ $\mathrm{mL}$ as resistant (Table 1).

MAMA-PCR. Strains characterized as resistant or intermediate, by MIC, were analyzed by MAMA-PCR (Table 2), described by Alonso et al. (2005). A 23SRNA-F forward primer was used in conjunction with the ERY2075 primer to detect the A2075G mutation. In parallel, the ERY2074 primer was used to detect the A2074C mutation. A $485 \mathrm{bp}$ amplicon was obtained for each reaction in the strains that presented the mutation. The PCR reaction had a final volume of $25 \mu \mathrm{l}$ containing: 1X PCR buffer (10mM Tris $\mathrm{HCl}, 1.5 \mathrm{mM} \mathrm{MgCl}, 50 \mathrm{mM} \mathrm{KCl}$ ( $\mathrm{pH} 8.3$ ), $1.5 \mathrm{mM} \mathrm{MgCl}_{2}, 5 \mu \mathrm{L}$ of DNA, $0.2 \mu \mathrm{M}$ of the $23 \mathrm{~S}$ rRNA-F primer and $0.2 \mu \mathrm{M}$ of ERY 2074 or ERY 2075 primer, $0.2 \mathrm{mM}$ of dNTP and $1 \mathrm{U}$ of Taq polymerase (Invitrogen, Brazil). The initial denaturation was carried out at $94^{\circ} \mathrm{C}$ for $5 \mathrm{~min}$, followed by 30 cycles of denaturation at $94^{\circ} \mathrm{C}$ for $30 \mathrm{~s}$, annealing at $59^{\circ} \mathrm{C}$ for $30 \mathrm{~s}$, extension at $72^{\circ} \mathrm{C}$ for $45 \mathrm{~s}$ and final extension at $72^{\circ} \mathrm{C}$ for $5 \mathrm{~min}$.

$\operatorname{erm}(\boldsymbol{B})$ gene detection. The $\operatorname{erm}(\mathrm{B})$ gene detection was performed in strains characterized as resistant or intermediate, following the PCR proposed by Zhang et al. (2016). The reaction contained 1X PCR buffer (10mM Tris $\mathrm{HCl}, 1.5 \mathrm{mM} \mathrm{MgCl}_{2}, 50 \mathrm{mM} \mathrm{KCl}$ (pH 8.3), $1.5 \mathrm{mM}$ $\mathrm{MgCl}_{2}, 0.2 \mathrm{mM}$ dNTP, $0.5 \mathrm{mM}$ of each primer and $1 \mathrm{U}$ of Taq polymerase (Invitrogen, Brazil). An initial cycle was used for denaturation at $94^{\circ} \mathrm{C}$ for $5 \mathrm{~min}$; followed by 30 cycles of amplification at $94^{\circ} \mathrm{C}$ for $30 \mathrm{~s}, 60^{\circ} \mathrm{C}$ for $30 \mathrm{~s}$ for annealing and $72^{\circ} \mathrm{C}$ for $45 \mathrm{~s}$ for extension. The final extension was performed at $72^{\circ} \mathrm{C}$ for $5 \mathrm{~min}$.

\section{RESULTS AND DISCUSSION}

From the intestinal content of 30 swines, 14 (46.6\%) strains of Campylobacter coli, and none of Campylobacter jejuni were isolated. The presence of $C$. coli in swine is more frequent than in birds, and this microorganism can be considered a natural inhabitant of the swine intestine (Varela et al. 2007). Kempf et al. (2017) and Gebreyes et al. (2005), as well as in this study, isolated only $C$. coli from swine feces. From the 20 samples of intestinal content from broiler chickens, 18 (90\%) strains of $C$. jejuni and two (20\%) of C. coli were obtained. Frasão et al. (2015), Chen et al. (2010), and Hald et al. (2000) also reported more significant colonization of $C$. jejuni in broiler chickens when compared to $C$. coli, demonstrating that this is the predominant species in broilers.

Table 1. Strains, origin, minimum inhibitory concentration (MIC) and molecular mechanisms involved in resistance in Campylobacter jejuni and Campylobacter coli strains

\begin{tabular}{|c|c|c|c|c|c|}
\hline Species & Origin & $\mathrm{MIC} \mu \mathrm{l} / \mathrm{mL}^{*}$ & A2075G & $\mathrm{A} 2074 \mathrm{C}$ & $\operatorname{erm}(\mathrm{B})$ \\
\hline C. coli & Swine/MG & $>128$ & + & - & - \\
\hline C. coli & Swine/MG & $>128$ & + & - & - \\
\hline C. coli & Swine/MG & $>128$ & + & - & - \\
\hline C. coli & Swine/MG & 128 & + & - & - \\
\hline C. coli & Swine/MG & $>128$ & + & - & - \\
\hline C. coli & Swine/MG & $>128$ & + & - & - \\
\hline C. coli & Swine/MG & $>128$ & + & - & - \\
\hline C. coli & Swine/MG & 128 & + & - & - \\
\hline C. coli & Swine/MG & $>128$ & + & - & - \\
\hline C. coli & Swine/MG & $>128$ & + & - & - \\
\hline C. coli & Swine/MG & $>128$ & + & - & - \\
\hline C. coli & Swine/MG & $>128$ & + & - & - \\
\hline C. coli & Swine/MG & $>128$ & + & - & - \\
\hline C. coli & Swine/MG & $>128$ & + & - & - \\
\hline C. jejuni & Broiler chicken/RJ & 16 & + & - & - \\
\hline C. jejuni & Broiler chicken/RJ & 16 & - & - & - \\
\hline C. jejuni & Broiler chicken/RJ & 16 & - & - & - \\
\hline C. jejuni & Broiler chicken/RJ & 1 & - & - & - \\
\hline C. jejuni & Broiler chicken/RJ & 0.5 & - & - & - \\
\hline C. jejuni & Broiler chicken/RJ & $<0.5$ & - & - & - \\
\hline C. jejuni & Broiler chicken/RJ & $<0.5$ & - & - & - \\
\hline C. jejuni & Broiler chicken/RJ & $<0.5$ & - & - & - \\
\hline C. coli & Broiler chicken/RJ & 0.5 & - & - & - \\
\hline C. jejuni & Broiler chicken/RJ & $<0.5$ & - & - & - \\
\hline C. jejuni & Broiler chicken/RJ & $<0.5$ & - & - & - \\
\hline C. jejuni & Broiler chicken/RJ & $<0.5$ & - & - & - \\
\hline C. coli & Broiler chicken/RJ & 0.5 & - & - & - \\
\hline C. jejuni & Broiler chicken/RJ & $<0.5$ & - & - & - \\
\hline C. jejuni & Broiler chicken/RJ & $<0.5$ & - & - & - \\
\hline C. jejuni & Broiler chicken/RJ & $<0.5$ & - & - & - \\
\hline C. jejuni & Broiler chicken/RJ & $<0.5$ & - & - & - \\
\hline C. jejuni & Broiler chicken/RJ & $<0.5$ & - & - & - \\
\hline C. jejuni & Broiler chicken/RJ & $<0.5$ & - & - & - \\
\hline C. jejuni & Broiler chicken/RJ & $<0.5$ & - & - & - \\
\hline
\end{tabular}

* Interpretation parameters according to CLSI (2013): $\leq 8 \mu \mathrm{l} / \mathrm{mL}=$ sensitive, $16 \mu \mathrm{l} / \mathrm{mL}=$ intermediate, $\geq 32 \mu \mathrm{l} / \mathrm{mL}=$ resistant.

Table 2. Primers used in the investigation of molecular mechanisms in Campylobacter jejuni and Campylobacter coli resistant to erythromycin

\begin{tabular}{ccccc}
\hline Gene & Primer & Sequence $\left(5^{\prime} \rightarrow 3^{\prime}\right)$ & Fragment & Reference \\
\hline 23S & RNS & TTAGCTAATGTTGCCCGTACCG & & \\
rRNA & ERY2075-R & TAGTAAAGGTCCACGGGGTCGC & $485 \mathrm{pb}$ & $\begin{array}{c}\text { Alonso et al. } \\
2005\end{array}$ \\
& ERY2074-R & AGTAAAGGTCCACGGGGTCTGG & & \\
erm(B) & erm(B)-F & GAAGGAGTGATTACATGAACAA & & Zho pb \\
& erm(B)-R & TCATAGAATTATTTCCTCCCGT & & 2016
\end{tabular}


The MIC of $C$. jejuni strains ranged from $\leq 0.5 \mu \mathrm{g} / \mathrm{mL}$ to $16 \mu \mathrm{g} / \mathrm{mL}$. In Brazil, Hungaro et al. (2015) did not observe the presence of strains resistant to erythromycin in isolates from chicken carcasses, however high frequency of strains resistant to this antimicrobial were reported in C. jejuni $(75 \%)$ and $C$. coli $(60 \%)$ isolated of children with diarrhea in the state of Minas Gerais (Rodrigues et al. 2015).

The $C$. coli strains from broiler chickens showed a MIC of $0.5 \mu \mathrm{g} / \mathrm{ml}$, being considered sensitive, while $C$. coli strains from swines were characterized as resistant, with two strains $(15.3 \%)$ showing a MIC of $128 \mu \mathrm{g} / \mathrm{ml}$ and twelve (85.7\%) with MIC $\geq 128 \mu \mathrm{g} / \mathrm{ml}$. Asakura et al., 2019 also detected resistance to erythromycin in $92 \%$ of $C$. coli strains obtained from swines in Japan. It is accepted that $C$. coli from swines has a high level of resistance to erythromycin (Egger et al. 2012), possibly due to the greater survival capacity of strains with mutations associated with resistance to macrolides when compared to C. jejuni (Bolinger et al. 2017). Regarding C. jejuni, it could be noted that the resistance to erythromycin is accompanied by a reduced ability to colonize birds, potentially contributing to the low incidence of resistance to macrolides (Bolinger et al. 2018). In the laboratory, strains of $C$. jejuni that had these mutations induced, in the 23S rRNA region, grew more slowly than their non-mutant clones and showed higher mortality, which may partially contribute to the low levels of resistance to macrolides observed in C. jejuni (Han et al. 2009). Several studies (Chen et al. 2010, Wang et al. 2014, Lim et al. 2016, Zhou et al. 2016, Zhang et al. 2016) have shown higher levels of resistance to erythromycin in $C$. coli compared to $C$ jejuni.

In this study, the A2075G mutation was found in all strains resistant to erythromycin, possibly one of the first reports. Studies on the molecular mechanisms involved in erythromycin resistance report this mutation as the leading cause of resistance in C. jejuni and C. coli. The A2074C mutation was not identified in any resistant strain in this study, which corroborates other studies that report being rare mutations and described in a few strains in the world (Payot et al. 2004, Lim et al. 2016, Wei \& Kang 2018). It was observed that a strain of $C$. jejuni with intermediate resistance had the A2075G mutation, suggesting that intermediate levels of resistance may also be related to this mutation. In the other two strains of C. jejuni with intermediate resistance, this mutation was not detected. Other mechanisms, such as the presence of point mutations in genes encoding ribosomal proteins and/or efflux pump mechanisms may be involved (Lehtopolku et al. 2011).

None of the strains tested had the erm(B) gene. Except for a description of this gene in Spain, made by Florez-Cuadrado et al. (2016) and a case of a woman who had traveled to Asia, and on returning to the USA presented a picture of campylobacteriosis from which a strain of $C$. jejuni with the erm(B) gene was isolated (Chen et al. 2018). Except in this case, all reports of positive strains for this gene have been detected in China (Qin et al. 2014, Wang et al. 2014, Zhang et al. 2016, Liu et al. 2017, 2019). Bolinger et al. (2018), when studying strains of Campylobacter spp. isolated from commercial turkey farms in the USA, as well as Kempf et al. (2017), studying strains isolated from swines in France, did not detect this gene in any of the strains that are resistant to erythromycin. The mechanism reported by these studies was also the presence of the A2075G mutation, corroborating that this is the most common resistance to erythromycin.

\section{CONCLUSIONS}

A high level of resistance ( $\geq 128 \mu \mathrm{g} / \mathrm{ml}$ ) to erythromycin was detected in Campylobacter coli strains isolated from swine by MIC, and the A2075G mutation was observed in all strains resistant to this antimicrobial. The $\mathrm{A} 2074 \mathrm{C}$ mutation and the erm(B) gene were absent in all strains studied.

The MAMA-PCR technique is a practical tool for detecting the molecular mechanisms involved in resistance to erythromycin in strains of Campylobacter jejuni and C. coli.

Ackowledgments.- This study was funded by the "Conselho Nacional de Desenvolvimento Científico e Tecnológico” (CNPq), Brazil.

Conflict of interest statement.- There are no conflicts of interest.

\section{REFERENCES}

Alonso R., Mateo E., Churruca E., Martinez I., Girbau C. \& FernándezAstorga A. 2005. MAMA-PCR assay for the detection of point mutations associated with high-level erythromycin resistance in Campylobacter jejuni and Campylobacter coli strains. J. Microbiol. Methods 63(1):99-103. <http://dx.doi.org/10.1016/j.mimet.2005.03.013><PMid:15927294>

Aquino M.H.C., Mangia A.H.R., Filgueiras A.L.L., Teixeira L.M., Ferreira M.C.S. \& Tibana A. 2002. Use of a multiplex PCR-based assay to differentiate Campylobacter jejuni and Campylobacter coli strains isolated from human and animal sources. Vet. J. 163(1):102-104. <http://dx.doi.org/10.1053/ tvjl.2001.0632><PMid:11749144>

Asakura H., Sakata J., Nakamura H., Yamamoto S. \& Murakami S. 2019. Phylogenetic diversity and antimicrobial resistance of Campylobacter coli from humans and animals in Japan. Microbes Environ. 34(2):146-154. <http://dx.doi.org/10.1264/jsme2.ME18115> <PMid:30905895>

Bolinger H. \& Kathariou S. 2017. The current state of macrolide resistance in Campylobacter spp.: trends and impacts of resistance mechanisms. Appl. Environ. Microbiol. 83(12):e00416-17.<http://dx.doi.org/10.1128/ AEM.00416-17><PMid:28411226>

Bolinger H.K., Zhang Q., Miller W.G. \& Kathariou S. 2018. Lack of evidence for erm(B) infiltration into erythromycin-resistant Campylobacter coli and Campylobacter jejuni from commercial turkey production in eastern North Carolina: a major turkey-growing region in the United States. Foodborne Pathog. Dis. 15(11):698-700.<http://dx.doi.org/10.1089/fpd.2018.2477> $<$ PMid:30096008>

Chen J.C., Tagg K.A., Joung Y.J., Bennett C., Watkins L.F., Eikmeier D. \& Folster J.P. 2018. Report of erm(B)+ Campylobacter jejuni in the United States. Antimicrob. Agents Chemother. 62(6):e02615-17. <http://dx.doi. org/10.1128/AAC.02615-17><PMid:29632015>

Chen X., Naren G.-W., Wu C.-M., Wang Y., Dai L., Xia L.-N., Luo P.-J., Zhang Q. \& Shen J.Z. 2010. Prevalence and antimicrobial resistance of Campylobacter isolates in broilers from China. Vet. Microbiol. 144(1/2):133-139. <http://dx.doi.org/10.1016/j.vetmic.2009.12.035><PMid:20116182>

CLSI 2010. Methods for Antimicrobial Dilution and Disk Susceptibility Testing of Infrequently Isolated or Fastidious Bacteria, Approved guideline-Second Edition. CLSI document M45-A2, Clinical and Laboratory Standards Institute, Wayne, PA.

CLSI 2013. Performance Standards for Antimicrobial Disk and Dilution Susceptibility Tests for Bacteria Isolated From Animals, Second Informational Supplement. CLSI document VET01-S2, Clinical and Laboratory Standards Institute, Wayne, PA.

EFSA \& ECDC 2018a. The European Union summary report on antimicrobial resistance in zoonotic and indicator bacteria from humans, animals and food in 2016. EFSA Journal 16(2):5182. <http://dx.doi.org/10.2903/j. efsa.2018.5182> 
EFSA \& ECDC 2018b. The European Union summary report on trends and sources of zoonoses, zoonotic agents and foodborne outbreaks in 2017. EFSA Journal 16(12):5500. <http://dx.doi.org/10.2903/j.efsa.2018.5500>

Egger R., Korczak B.M., Niederer L., Overesch G. \& Kuhnert P. 2012. Genotypes and antibiotic resistance of Campylobacter coli in fattening pigs. Vet. Microbiol. 155(2/4):272-278. <http://dx.doi.org/10.1016/j.vetmic.2011.08.012>

Florez-Cuadrado D., Ugarte-Ruiz M., Quesada A., Palomo G., Domínguez L. \& Porrero M.C. 2016. Description of an erm(B)-carrying Campylobacter coli isolate in Europe. J. Antimicrob. Chemother. 71(3):841-843. <http:// dx.doi.org/10.1093/jac/dkv383><PMid:26604242>

Frasão B.S., Côrtes L.R., Nascimento E.R., Cunha N.C., Almeida V.L. \& Aquino M.H.C. 2015. Detecção de resistência às fluoroquinolonas em Campylobacter isolados de frangos de criação orgânica. Pesq. Vet. Bras. 35(7):613-619. <http://dx.doi.org/10.1590/S0100-736X2015000700003>

Gebreyes W.A., Thakur S. \& Morrow W.E.M. 2005. Campylobacter coli: prevalence and antimicrobial resistance in antimicrobial-free (ABF) swine production systems. J. Antimicrob. Chemoter. 56(4):765-768. <http://dx.doi.org/10.1093/jac/dki305><PMid:16120624>

Giacomelli M., Andrighetto C., Rossi, F., Lombardi A., Rizzotti L., Martini M. \& Piccirillo A. 2012. Molecular characterization and genotypic antimicrobial resistance analysis of Campylobacter jejuni and Campylobacter coli isolated from broiler flocks in northern Italy. Avian Pathol. 41(6):579-588. <http://dx.doi.org/10.1080/03079457.2012.734915><PMid:23237371>

Gibbons C.L., Mangen M.J., Plass D., Havelaar A.H., Brooke R.J., Kramarz P., Peterson K.L., Stuurman A.L., Cassini A., Fèvre E.M. \& Kretzschmar M.E. 2014. Measuring underreporting and under-ascertainment in infectious disease datasets: a comparison of methods. BMC Public Health 14:147. <http://dx.doi.org/10.1186/1471-2458-14-147><PMid:24517715>

Hald B., Wedderkopp A. \& Madsen M. 2000. Thermophilic Campylobacter spp. in Danish broiler production: a cross-sectional survey and a retrospective analysis of risk factors for occurrence in broiler flocks. Avian Pathol. 29(2):123-131. <http://dx.doi.org/10.1080/03079450094153> <PMid:19184798>

Han F., Pu S., Wang F., Meng J. \& Ge B. 2009. Fitness cost of macrolide resistance in Campylobacter jejuni. J. Antimicrob. Agents 34(5):462-466. <http:// dx.doi.org/10.1016/j.ijantimicag.2009.06.019><PMid:19651494>

Han X., Zhu D., La H., Zeng H., Zhou K., Zou L., Wu C., Han G. \& Liu S. 2016. Prevalence, antimicrobial resistance profiling and genetic diversity of Campylobacter jejuni and Campylobacter coli isolated from broilers at slaughter in China. Food Control 69:160-170. <http://dx.doi.org/10.1016/j. foodcont.2016.04.051>

Harmon K.M., Ransom G.M. \& Wesley I.V. 1997. Differentiation of Campylobacter jejuni and Campylobacter coli by polymerase chain reaction. Mol. Cel. Probes 11(3):195-200. <http://dx.doi.org/10.1006/mcpr.1997.0104> $<$ PMid:9232618>

Hungaro H.M., Mendonça R.C.S., Rosa V.O., Badaró A.C.L., Moreira M.A.S. \& Chaves J.B.P. 2015. Low contamination of Campylobacter spp. on chicken carcasses in Minas Gerais state, Brazil: molecular characterization and antimicrobial resistance. Food Control 51:15-22. <http://dx.doi. org/10.1016/j.foodcont.2014.11.001>

Kempf I., Kerouanton A., Bougeard S., Nagard B., Rose V., Mourand G., Osterberg J., Denis M. \& Bengtsson B. O. 2017. Campylobacter coli in organic and conventional pig production in France and Sweden: prevalence and antimicrobial resistance. Front. Microbiol. 8:955. <http://dx.doi. org/10.3389/fmicb.2017.00955><PMid:28611754>

Ladely S.R., Meinersmann R.J., Englen M.D., Fedorka-Cray P. J. \& Harrison M.A. 2009. 23S rRNA Gene mutations contributing to macrolide resistance in Campylobacter jejuni and Campylobacter coli. Foodborne Pathog. Dis. 6(1):91-98.<http://dx.doi.org/10.1089/fpd.2008.0098><PMid:19014274>

Lehtopolku M., Kotilainen P., Haanperä-Heikkinen M., Nakari U.M., Hänninen M.L., Huovinen P., Siitonen A., Eerola E., Jalava J. \& Hakanen A.J. 2011. Ribosomal mutations as the main cause of macrolide resistance in Campylobacter jejuni and Campylobacter coli. Antimicrob. Agents Chemother. 55(12):59395941. <http://dx.doi.org/10.1128/AAC.00314-11><PMid:21911571>

Lim S.K., Moon D.-C., Chae M.H., Kim H.J., Nam H.-M., Kim S.-R., Jang G.-C., Lee K., Jung S.-C. \& Lee H.S. 2016. Macrolide resistance mechanisms and virulence factors in erythromycin-resistant Campylobacter species isolated from chicken and swine feces and carcasses. J. Vet. Med. Sci. 78(12):17911795. <http://dx.doi.org/10.1292/jvms.16-0307><PMid:27593510>

Liu D., Deng F., Gao Y., Yao H. Shen Z., Wu C. Wang Y. \& Shen, J. 2017. Dissemination of erm(B) and its associated multidrug-resistance genomic islands in Campylobacter from 2013 to 2015. Vet. Microbiol. 204:20-24. <http://dx.doi.org/10.1016/j.vetmic.2017.02.022> <PMid:28532801>

Liu D., Liu W., Lv Z., Xia J., Li X., Hao Y., Zhou Y., Yao H., Liu Z., Wang Y., Shen J., Ke Y. \& Shen, Z. 2019. Emerging erm(B)-mediated macrolide resistance associated with novel multidrug resistance genomic islands in Campylobacter. J. Antimicrob. Agents 63(7):e00153-19. <http://dx.doi.org/10.1128/ AAC.00153-19>

Luangtongkum T., Jeon B., Han J., Plummer P., Logue C.M. \& Zhang Q. 2009. Antibiotic resistance in Campylobacter: emergence, transmission and persistence. Future Microbiol. 4(2):189-200. <http://dx.doi. org/10.2217/17460913.4.2.189><PMid:19257846>

Maćkiw E., Korsak D., Rzewuska K., Tomczuk K., \& Rożynek E. 2012. Antibiotic resistance in Campylobacter jejuni and Campylobacter coli isolated from food in Poland. Food Control 23(2):297-301.<http://dx.doi.org/10.1016/j. foodcont.2011.08.022>

Payot S., Avrain L., Magras C., Praud K., Cloeckaert A. \& Chaslus-Dancla E. 2004. Relative contribution of target gene mutation and efflux to fluoroquinolone and erythromycin resistance, in French poultry and pig isolates of Campylobacter coli. Int. J. Antimicrob. Agents 23(5):468-472. <http://dx.doi.org/10.1016/j.ijantimicag.2003.12.008>

Pyörälä S., Baptiste K.E., Catry B., Duijkeren E.van., Greko C., Moreno M.A., Pomba M.C.M.F., Rantala M., Ružauskas M., Sanders P., Threlfall E.J., TorrenEdo J. \& Törneke K. 2014. Macrolides and lincosamides in cattle and pigs: use and development of antimicrobial resistance. Vet. J. 200(2):230-239. <http://dx.doi.org/10.1016/j.tvjl.2014.02.028> <PMid:24685099>

Qin S., Wang Y., Zhang Q., Zhang M., Deng F., Shen Z., Wu C., Wang S., Zhang J. \& Shen J. 2014. Report of ribosomal RNA methylase gene erm(B) in multidrugresistant Campylobacter coli. J. Antimicrob. Chemother. 69(4):964-968. <http://dx.doi.org/10.1093/jac/dkt492> <PMid:24335515>

Qin S.S., Wu C.M., Wang Y., Jeon B., Shen Z.Q., Wang Yu, Zhang Q. \& Shen J.Z. 2011. Antimicrobial resistance in Campylobacter coli isolated from pigs in two provinces of China. Int. J. Food Microbiol. 146(1):94-98. <http://dx.doi.org/10.1016/j.ijfoodmicro.2011.01.035><PMid:21349598>

Rodrigues C.G., Melo R.T., Fonseca B.B., Martins P.A., Ferreira F.A., Araújo M.B.J. \& Rossi D.A. 2015. Occurrence and characterization of Campylobacter spp. isolates in dogs, cats and children. Pesq. Vet. Bras. 35(4):365-370. <http:// dx.doi.org/10.1590/S0100-736X2015000400009>

Rosner B.M., Schielke A., Didelot X., Kops, F., Breidenbach J., Suerbaum S. \& Stark K. 2017. A combined case-control and molecular source attribution study of human Campylobacter infections in Germany, 2011-2014. Scient. Reports 7(1):5139. <http://dx.doi.org/10.1038/s41598-017-05227-x>

Sambrook J. \& Russell D.W. 2006. Purification of nucleic acids by extraction with phenol:chloroform. CSH Protoc. 2006(1):pdb.prot4455. <http:// dx.doi.org/10.1101/pdb.prot4455> <PMid:22485786>

Varela N.P., Friendship R. \& Dewey C. 2007. Prevalence of resistance to 11 antimicrobials among Campylobacter coli isolated from pigs on 80 growerfinisher farms in Ontario. Can. J. Vet. Res. 71(3):189-194. < PMid:17695593>

Vázquez-Laslop N. \& Mankin A.S. 2018. How Macrolide antibiotics work. Trends Biochem. Sci. 43(9):668-684. <http://dx.doi.org/10.1016/j. tibs.2018.06.011><PMid:30054232>

Wang Y., Zhang M., Deng F., Shen Z., Wu C., Zhang J., Zhang Q. \& Shen J. 2014. Emergence of multidrug-resistant Campylobacter species isolates with a 
horizontally acquired rRNA methylase. Antimicrob. Agents Chemother. 58(9):5405-5412. <http://dx.doi.org/10.1128/AAC.03039-14> $<$ PMid:24982085>

Wei B. \& Kang M. 2018. Molecular basis of macrolide resistance in Campylobacter strains isolated from poultry in South Korea. Biomed Res. Int. 2018:1-9. <http://dx.doi.org/10.1155/2018/4526576><PMid:30069469>

WHO 2013. Critically important antimicrobials for human medicine. World Health Organization, Geneva.

Wiesner R.S., Hendrixson D.R. \& Dirita V.J. 2003. Natural transformation of Campylobacter jejuni requires components of a type II secretion system. J. Bacteriool. 185(18):5408-5418.<http://dx.doi.org/10.1128/jb.185.18.54085418.2003><PMid:12949093>
Wilson D.J., Gabriel E., Leatherbarrow A.J.H., Cheesbrough J., Gee S., Bolton E., Fox, A., Fearnhead P., Hart C.A. \& Diggle P.J. 2008. Tracing the source of campylobacteriosis. PLoS Genetics 4(9):e1000203. <http://dx.doi. org/10.1371/journal.pgen.1000203><PMid:18818764>

Zhang A., Song L., Liang H., Gu Y., Zhang C., Liu X., Zhang J. \& Zhang M. 2016. Molecular subtyping and erythromycin resistance of Campylobacter in China. J. Applied Microbiol. 121(1):287-293. <http://dx.doi.org/10.1111/ jam.13135><PMid:26999516>

Zhou J., Zhang M., Yang W., Fang Y., Wang G. \& Ho F. 2016. A seventeen-year observation of the antimicrobial susceptibility of clinical Campylobacter jejuni and the molecular mechanisms of erythromycin-resistant isolates in Beijing, China. Int. J. Infec. Dis. 42:28-33.<http://dx.doi.org/ 10.1016/j. ijid.2015.11.005> 